\title{
"MARÉS DAS REBELDIAS EM ABAETETUBA": DOS RIOS DA EXISTÊNCIA À RESISTÊNCIA DOS TERRITÓRIOS NA AMAZÔNIA PARAENSE, BAIXO TOCANTINS
}

\section{"Tides of the rebels in Abaetetuba": from the rivers of the existence to the resistance of the territories in the paraense Amazon, Baixo Tocantins}

\section{"Mareas de las rebeldías en Abaetetuba": de los ríos de la existencia hasta la resistencia de los territorios en la Amazonia paraense, Baixo Tocantins}

\author{
Osmana Dias Gonçalves \\ Pós-Graduanda em Geotecnologias Aplicadas ao Planejamento Ambiental \\ e Desenvolvimento Territorial Rural (UFPA) \\ osmanadias@gmail.com \\ Jondison Cardoso Rodrigues \\ Doutor em Desenvolvimento Socioambiental e Pós-Doutorando em \\ Desenvolvimento Regional (PPGMDR/UNIFAP) \\ jondisoncardosorodrigues@gmail.com \\ José Sobreiro Filho \\ Docente do Programa de Pós-Graduação em Geografia (PPGEO)/UFPA e \\ o Programa de Pós-Graduação em Desenvolvimento Territorial na América \\ Latina e Caribe/UNESP \\ sobreirounesp@gmail.com
}

Artigo enviado para publicação em 30/03/2019 e aceito em 22/05/2019

DOI: $10.12957 /$ tamoios.2019.41209

\begin{abstract}
Resumo
A dinâmica de "ocupação" colonizadora-espoliadora e a formação socioeconômica da Amazônia são marcadas por uma trajetória de exploração, perdas, danos, conflitos/conflitualidades e resistências. Atualmente, principalmente comunidades e povos tradicionais da região vêm sofrendo com a emergência e a materialização de novas ameaças e tensões com empresas transnacionais, latifundiários, madeireiros, grileiros, elites locais e regionais. Conflitos decorrentes do processo de territorialização por agentes econômicos ligados à logística de transporte e portuária, sobretudo, os do agronegócio, localizados no Oeste do Pará e Baixo Tocantins (Abaetetuba). Partindo desse campo de tensões e resistências, este artigo tem como objetivo identificar e analisar as ações de resistência realizadas pela Paróquia Nossa Senhora Rainha da Paz em face da territorialização portuária do agronegócio, em Abaetetuba, Pará (2016-2018).
\end{abstract}

Palavras-chave: Resistência; Amazônia; Abaetetuba; Igreja Católica.

\begin{abstract}
The dynamics of the "occupation" based on colonization and spoliation, and the socioeconomic formation of Amazonia are marked by a trajectory of exploitation, losses, damages, conflicts/conflictuality and resistances. Currently, communities and traditional peoples of the amazonic region have been suffering in face of the emergence and materialization of new threats and tensions created by transnational companies, landowners, wood extraction, "grileiros", local and regional elites. The conflicts emerges from the process of territorialization by economic agents related to transportation and port logistics, especially those that suport the agribusiness, located in the West of Pará and Baixo Tocantins region (Abaetetuba). From the conflitctive atmosphere of tensions and resistances this article aims to identify and analyze the resistance actions carried out by the Nossa Senhora Rainha da Paz Parish in front of agribusiness port territorialization in Abaetetuba, Pará (2016-2018).
\end{abstract}

Keywords: Resistance; Amazon; Abaetetuba; Catholic Church. 


\section{Resumen}

A dinámica de ocupación colonizadora-expoliadora y la formación socioeconómica de la Amazonia son marcadas por una historia, una trayectoria de explotación, pérdidas, daños, conflictos/conflictividades y resistencias. Actualmente, principalmente comunidades y pueblos tradicionales de la región vienen sufriendo con la emergencia y la materialización de nuevas amenazas y tensiones con las empresas transnacionales, terratenientes, madereros, usurpadores de tierras, élites locales e regionales. Conflictos derivados del proceso de territorialización por agentes económicos ligados a la logística de transporte y portuario, sobre todo, los del agro negocio, localizados en el Oeste de Pará y el Bajo Tacantins (Abaetetuba). Partiendo de ese campo de tensiones y resistencias, este artículo tiene como objetivo identificar y analizar las acciones de resistencia realizadas por la Parroquia Nuestra Señora Reina de la Paz frente a la territorialización portuaria del agro negocio, en Abaetetuba, Pará (2016-2018).

Palavras clave: Resistencia; Amazonia; Abaetetuba; Igreja Católica. 


\section{Introdução}

A ocupação colonial da Amazônia e sua formação socioeconômica foram marcadas por uma trajetória de exploração, perdas e danos, conforme Castro e Campos (2015) e Loureiro $(2002,2012)$; bem como pela produção de imaginário de que: 1) a natureza amazônica seria resistente, superabundante, autorrecuperável e inesgotável; 2) a região seria caracterizada como um macrossistema homogêneo de floresta, rios e igarapés, assim como também uniforme com relação à cultura, crenças, tradições e territorialidades; 3 ) seria uma grande área desabitada; 4) haveria um povo sem história e caracterizado como "bárbaros, primitivos, rudes, preguiçosos e, possivelmente desprovidos de uma alma!" (LOUREIRO, 2002, p. 109); 5) existiria suposta imprescindibilidade do progresso civilizatório", entendendo-o como o "caminho natural" (CASTRO et al, 2018).

Para Loureiro (2002), o imaginário produzido foi de uma região a ser desenvolvida e integrada ao Brasil, visto que a natureza, em geral, bem como os povos originários, seriam a expressão do primitivismo e do atraso regional. Tal compreensão constituiu uma política de inferiorização lastreada pelos ideais da colonialidade que subordinaram diversos territórios e todas as suas dimensões; especialmente no que se refere à cultura e às construções de saberes e práticas sociais. Conforme Castro et al (2018), houve maior reforço dessa via colonial com a expansão capitalista que se inseriu na Amazônia, desde a função espoliadora, no contexto agroexportador/neoextrativista ${ }^{2}$, frente à construção da dependência socioeconômica subalterna.

Essa construção de dependência está relacionada a um "padrão econômico voltado para a exportação que, desde o início da colonização até hoje é a motivação dominante na ocupação regional " (BECKER, 2001, p. 135). Uma das práticas coloniais comuns é tornar invisíveis os povos e comunidades tradicionais da Amazônia, como forma de "desobstruir" entraves ou processos judiciais. Em outras palavras, esta prática compõe o perverso cabedal de táticas corriqueiras que têm facilitado a legitimação, ordenamento, estruturação e construção de parcerias/alianças para que as hegemonias político-econômicas se mantenham, avancem na dominação, governança e controle dos territórios (CASTRO, 2018); sobretudo, aos auspícios de uma razão neoliberal que drena as forças de um Estado e agências supranacionais desigualmente promíscuas, objetivando amplificar as práticas espoliadoras.

Indubitavelmente, não se leva em consideração a vivência desses povos, suas formas culturais e originárias para as construções emancipatórias, mas apenas a lógica perversa da espoliação de recursos materiais e imateriais (naturais e de saberes). Em consequência, desenvolvem-se as conflitualidades, sendo outro processo fundamental para se compreender não somente a questão agrária da Amazônia, mas também sua ocupação colonial, até a atualidade. No momento presente, os povos tradicionais da região amazônica também estão sob ameaças, vivenciando as diversas tensões com empresas transnacionais, latifundiários, madeireiros, grileiros, elites locais e regionais, como, por exemplo, em virtude da territorialização de agentes econômicos ligados à logística de transporte e portuária, sobretudo, no que tange ao agronegócio no Oeste do Pará e no Baixo Tocantins (Abaetetuba).

Partindo desse campo de tensões e resistências, nosso artigo tem como escopo identificar e analisar as ações de resistência realizadas pela Paróquia Nossa Senhora Rainha da Paz em face da territorialização portuária do agronegócio, em Abaetetuba-PA (2016-2018) ${ }^{3}$. Assim, realizamos uma análise de forma crítica do processo de espoliação/despossessão, aos auspícios do debate sobre "economia de espoliação", segundo Harvey (2012, p. 17), particularmente de comunidades e povos tradicionais 
frente a essa territorialização de grandes agentes econômicos capitalistas. Ademais, também contrapomos a essa lógica o papel que instituições, pertencentes à Igreja Católica, como na análise a Paróquia Nossa Senhora Rainha da Paz, vêm desenvolvendo nas comunidades de bases, especialmente ações que visam despertar os cidadãos/populações (particularmente tradicionais) para resistência e a luta pelos seus direitos.

A relevância do artigo deve-se à difusão do debate sobre as contrahegemonias na Amazônia, diante da expansão de grandes projetos, bem como visa, também, possibilitar a identificação de bases históricas e materiais do conflito/conflitualidade e ações práticas de resistência, para que se possa também compreender "quais são as raízes das contradições da atualidade e que confluíram para o processo de insurreições políticas organizadas e a formação de movimentos socioterritoriais camponeses" (SOBREIRO-FILHO, 2013, p. 13).

Para o alcance desses objetivos, realizamos os respectivos procedimentos metodológicos: levantamento e revisão bibliográfica sobre o debate de território e territorialidade; a realização de entrevistas no município de Abaetetuba, focando nos agentes do campo de atuação de resistência e organização das comunidades; e, por fim, a análise de documentos históricos da Paróquia Nossa Senhora Rainha da Paz, porém, todos fincados na pesquisa-ação-participante, "concebida e realizada em estreita associação com uma ação ou com a resolução de um problema coletivo e no qual os pesquisadores e participantes representativos da situação ou do problema estão envolvidos de modo cooperativo ou participativo" (THIOLLENT, 2011, p. 20).

Com o objetivo de dar embasamento e melhor compreensão crítico-analítica para a discussão, buscamos a literatura especializada acerca da Amazônia, tais como: Castro (2012, 2017, 2018) e Violeta Loureiro (2002). No que se refere aos debates teóricoconceituais, houve diálogo com Haesbaert (2005, 2007), Fernandes (2005, 2009, 2013a, 2013b) e Sobreiro Filho (2013, 2015a, 2015b, 2016), visando amplificar a compreensão da análise dos conceitos de território e movimentos socioterritoriais. Além da melhor compreensão de como os grandes projetos vêm se desencadeando na Amazônia, estabelecemos diálogo com as contribuições de Castro (2012, 2017) e Rodrigues (2012, 2018a; 2018b), especialmente no que se refere ao avanço de exportação de commodities (agrícolas e minerais), consequentemente, quanto à "necessidade" da ampliação da logística (para soldagem a cadeias produtivas globais), estabelecemos diálogo com as contribuições de Castro (2012, 2017) e Rodrigues (2012, 2018a, 2018b).

Por fim, destacamos que o artigo está organizado em quatro seções. A primeira, de caráter introdutório, com a apresentação da questão desenvolvida. Na segunda, buscamos dar foco à compreensão do debate sobre movimentos socioterritoriais, conflitualidades e as resistências nas Comunidades Eclesiais de Base (CEBs). Em seguida, na terceira parte, realizamos análise referente à atuação das CEBs, no município de Abaetetuba - PA, compreendendo sua atuação a partir da combinação eclesial e social. Na quarta seção, apresentamos as práticas ribeirinhas de resistências, motivadas pela paróquia das ilhas, frente ao projeto portuário da Cargill. E, por último, apresentamos nossas considerações finais.

\section{Movimentos socioterritoriais, conflitualidade e a resistência das comunidades eclesiais de base, na fronteira da Amazônia Oriental}

A compreensão sobre os movimentos socioterritoriais se estabelece a partir de uma análise de luta pelo território, sendo assim, esta categoria emerge como algo central na leitura geográfica. Desse modo, consideramos que tal reflexão parte do fato de que, 
no território, encontram-se diferentes disputas, mediadas por distintos interesses por apropriação, produção e/ou ressignificação de uma determinada porção do espaço, caracterizada pelas relações de governança, tão logo "o território configura-se como a essência dos movimentos socioterritoriais" (SOBREIRO FILHO, 2016, p. 99). Nesse sentido, falar de movimentos socioterritoriais é estabelecer a relação de resistências mediante as conflitualidades que possam desencadear no e pelo território.

Assim sendo, as influências que se apresentam no território estão relacionadas com o poder tanto nas formas de dominação como nas de apropriação (HAESBAERT, 2005). Por isso, quando se trata de um território de populações tradicionais, o capitalismo, para exercer seu controle, precisa desterritorializar, a fim de que tenha total domínio ou, inclusive, subordinar as relações socioterritoriais e/ou o território imaterial (SOBREIRO FILHO, 2016). Logo, a luta pelo território significa um ato de confronto político, no qual a resistência significa mais do que luta pela terra, mas a afirmação do próprio "ser" socioterritorial e da imprescindibilidade do território neste momento histórico.

O território não se restringe somente a uma relação política, devido à multidimensionalidade (política, social, econômica, cultural, ambiental), conforme aponta Fernandes (2009) e Haesbaert (2005). Como exemplo, podemos verificar que a perda política do território para os povos tradicionais significa também a perda da identidade, dos saberes, dos lócus sacros. É sabido que boas parcelas destas relações estão lastreadas pela incorporação de novas terras agricultáveis e espoliação de recursos naturais, conforme aponta Castro:

Os interesses econômicos mundiais sobre os recursos naturais de solo e subsolo têm levado, continuamente, ao aumento das pressões sobre os territórios mais preservados no mundo, como é o caso da Amazônia com maior incidência de terras agriculturáveis, de florestas com rica biodiversidade e água abundante (2017, p. 22).

Não obstante, do contexto agrário brasileiro, a expansão do capital e sua metabolização de recursos naturais e humanos na Amazônia rural, têm acentuado os conflitos entre camponeses e originários/tradicionais e as faces da concentração (latifundiários e o agronegócio) como parte da conflitualidade gerada pelo capitalismo em relação direta com o Estado. De um lado, a busca pelo monopólio da terra, pela exploração do trabalho, pela espoliação, pela subordinação/integração, pela financeirização e commoditização, pela expropriação e pela concentração do capital; do outro lado, a permanência dos povos tradicionais nas terras amazônicas, plantando e cultivando suas relações, vivências, saberes e tradições, a fim de manter a própria identidade e cosmovisões.

Para Fernandes (2009, p. 201), nas "diferentes relações sociais e políticas territórios são produzidos e destruídos em permanentes conflitos, gerando complexas conflitualidades". Logo, a territorialização do capital nos territórios tradicionais produz disputas, que emergem em tensões, promovendo a "territorialização desterritorialização - reterritorialização de diferentes relações sociais" (FERNANDES, 2013, p. 223). Nesse sentido, entende-se que o capital promove divergências, nas quais a conflitualidade representa, ao mesmo tempo, o desdobramento de insatisfações geradas a partir das imposições de um modelo de desenvolvimento insustentável. Sendo, então, o território um espaço e uma pauta de lutas, conflitos, existência e resistências.

A Amazônia encontra-se na lógica desse campo de tensões, nas disputas de territórios para exploração e expansão capitalista. Apresenta sociometabolismo 
insustentável, o neoextrativista, pois "não levará ao desenvolvimento, porque os novos empreendimentos estão constituídos à base de enclaves de produção de semi-elaborados para exportação” (LOUREIRO, 2002, p. 118). Isso significa que o capital espoliador busca, atualmente, não apenas matérias primas, mas o território no seu sentido concreto de manifestação, inclusive, de soberania nacional, como forma de intensificar o processo de exploração, gerando a concentração de riqueza para fora. Como enfatiza Loureiro:

\begin{abstract}
Ao longo de sua história, a Amazônia tem gerado sempre mais recursos para fora (Metrópole e Federação) do que tem recebido como retorno; tem sido, permanentemente, um lugar de exploração, abuso e extração de riquezas em favor de outras regiões e outros povos. Mesmo nos últimos trinta anos, quando grandes investimentos foram feitos em infra-estrutura, estes visaram possibilitar a exploração de riquezas em favor da Federação (LOUREIRO, 2002, p,108).
\end{abstract}

A reflexão de Loureiro (2002) é coerente quando se pensa a Amazônia se tornando o berço de interesses de empresas transnacionais interessadas não somente em sua dimensão espacial e situação geográfica estratégica, mas também em seus recursos naturais, com o fito de se apropriar dos territórios, financeirizar-commoditizar a natureza, propiciar o enriquecimento para fora, inclusive de outros países.

Castro (2012) e Rodrigues (2018a; 2018b), apontam que interesses sobre a Amazônia se insere no processo de integração dos países sul-americanos, por meio do plano Iniciativa para a Integração da Infraestrutura da América do Sul (IIRSA) e o Programa de Aceleração de Crescimento (PAC). Ambos em uma "integração competitiva, adotando um modelo de modernização com base em megaprojetos de investimentos", sendo então "programas voltados para a logística de transporte, energia e comunicação" (CASTRO, 2012, p. 46).

Esses programas baseiam-se na lógica de interesse mercadológica, com o propósito de ascensão da economia movida pela competitividade, de um desenvolvimento territorial, porém nos moldes capitalista, em que as classes subalternas continuarão na marginalização. Nesse emblema os conflitos territoriais se sobressaem, numa modernização movida pela exploração das materializações do território (CASTRO et al, 2014; RODRIGUES; RODRIGUES; CASTRO, 2014).

Esses projetos estão relacionados à dinâmica de integração e, ao mesmo tempo, como inserção no mercado competidor do agronegócio, a exemplo da produção de complexos portuários (RODRIGUES; RODRIGUES, 2015), dentre os a Amazônia tem destaque, nessa competição via escoamento de commodities, como assinalado por Rodrigues (2018b, p. 203):

Essa lógica, via políticas públicas portuárias, seria criar estratégias para reduzir o tempo de armazenamento de mercadorias, promover a maior fluidez e o aumento da integração entre os elementos do sistema complexo de produção mundial, de relações e redes informacionais/relacionais e financeiras.

Nesse caso, o encurtamento das distâncias com o mercado de destino de produtos do agronegócio facilita não só o escoamento, mas também o nível de lucro para o capital. Assim sendo, o Projeto Arco Norte está conectado a essa dinâmica de mercados do agronegócio, promovendo os portos de circulação de commodities, assim como integrando-o à lógica de construção e/ou ampliação de estradas e ferrovias, engendrando aos grandes corredores logísticos (RODRIGUES, 2018a). 
Os corredores logísticos têm toda uma função de "usos para deslocamento dos principais produtos da economia brasileira: Complexo de soja e milho; Petróleo e combustíveis; Minério de ferro; açúcar; carne; e, automóvel. O complexo soja é a mercadoria que possui protagonismo" (RODRIGUES, 2018b, p. 212), promove a ampliação territorial ou a conexão ao circuito produtivo-financeiro internacional de commodities, como resultado de um conjunto de condições técnicas e políticas forjadas (RODRIGUES, 2018b, p. 211). Logo, toda essa dinâmica leva em consideração uma série de fatores que se dispõem nesse fluxo de conexões que envolvem os mercados do agronegócio, porém, apenas em sua esfera material, renegando as "simbologias" -a cultura, os modos de vida, as identidades- que cada território carrega consigo.

Segundo Haesbaert (2005, p. 6776), "todo território é, ao mesmo tempo e obrigatoriamente, em diferentes combinações, funcional e simbólico, pois exercemos domínio sobre o espaço tanto para realizar 'funções' quanto para produzir 'significados'.". No entanto, a lógica capitalista, ao buscar invisibilizar os povos tradicionais, nega toda essa dimensão imaterial produzida nos territórios. Assim, traz uma concepção de território apenas funcional, nesse caso, que esteja voltada à dinâmica do capital.

É justamente nesta redoma de contradições engendradas pela lógica metabólica do capital que os movimentos socioterritoriais protagonizam ações de resistência. Nessa concepção, entende-se que "os movimentos socioterritoriais têm o território não só como trunfo, mas este é essencial para sua existência” (FERNANDES, 2005, p. 31). Estabelecendo sua soberania e ao mesmo tempo buscando políticas de desenvolvimento territorial que visem à afirmação dos povos tradicionais. Se, por um lado, o capitalismo, em suas formas violentas de territorialização do agronegócio, busca subordinar os territórios tradicionais constantemente, a reação advinda desses povos em meio às ameaças caracteriza-se pela resistência.

Partindo dessa análise, compreendem-se as Comunidades Eclesiais de Base (CEBs), no âmbito institucional, como Igreja Católica, enquanto um movimento socioespacial, mas também socioterritorial ${ }^{4}$. A perspectiva das CEBs busca dar atenção ao preferencial aos pobres (BETO, 1981; HEWITT, 1986; 1990; COUTINHO, 2009; SOUZA, 2018), estimular e integrar a um movimento de "inclusão dos pobres" no engajamento político, na defesa dos territórios de vida e projeto de afirmação da vida, e da identidade social, com o encorajamento de formulações de estratégias contrahegemônicas, a formação de agentes autênticos da transformação social e política. Portanto, contrapondo-se e conflitando-se com o processo de territorialização capitalista.

Segundo Alencar e Oliveira (2015, p. 1143):

As CEBs apresentam no seu modo ser e atuar no contexto social um aspecto dinâmico e participativo para as mudanças na realidade brasileira, sendo consideradas como um movimento popular que propõe mudanças, com ações e práticas participativas nas decisões do país de forma significativa para transformação das estruturas dominantes que imperam no país.

Porém, é nessa concepção eclesial, com um olhar sensível à causa dos menos favorecidos, que as CEBs emergem face ao campo social. Motivadas pela Teologia da Libertação, desenvolvem construções políticas no campo teórico e prático que visem um despertar para as reais situações desencadeadoras de opressão. Assim:

Foi na raiz do processo de ocupação desses espaços, no fim dos anos 1960 e início dos anos 1970, que a Igreja passou a se posicionar frente ao desenvolvimento capitalista no campo. Os efeitos perversos dessa expansão 
começaram a ecoar nas Igrejas locais, ou melhor, passaram a ser fatos cotidianos e visíveis aos clérigos de diversas paróquias e dioceses do país, com destaque para a região da Amazônia Legal (MITIDIERO JUNIOR, 2010, p. 243).

Segundo Souza (2018), as CEBs foram capazes de articular: Religiosidade popular, sabedoria bíblica, piedade popular, organização popular e consciência política. E essa linha de pensamento e ação política são expressas nas CEBs na "Amazônia Tocantina" (Baixo Tocantins), cuja postura pautou-se em posicionamento de formação, sobretudo, de denunciadora das problemáticas que insurgiam com a chegada do modelo explorador capitalista, na região Amazônica. Isso porque "Nas Cebs o compromisso [é] com a família, trabalho, bairro e a comunidade local toma destaque" (SOUZA, 2018, p. 13) e "A voz do trabalhador rural, da mulher do campo, dos favelados, Sem terra, Negros, Indígenas e operários começam a ecoar" (SOUZA, 2018, p. 14).

As CEB's eram também uma ressonância de membros da igreja católica, como Dom Pedro Casaldáglia ${ }^{5}$. Primeiro bispo a tomar a postura de escrever uma carta denúncia sobre as opressões que se desencadeavam sobre os povos amazônicos com a chegada de grandes empreendimentos. A carta foi divulgada em 10 de outubro de 1971 e intitulada de "Uma Igreja da Amazônia em Conflito com o Latifúndio e a Marginalização Social". Representou o despertar de outros bispos que também proporcionaram uma nova visão da Igreja, referente à sua missão social.

Da prelazia de São Félix [Mato Grosso], da qual foi primeiro bispo e fundador, Dom Casaldáliga tornou-se o porta-voz para dar a conhecer ao Brasil e ao mundo inteiro as condições de vida de agricultores e índios.

A partir desse canto perdido do mundo, injustiças foram denunciadas, sacudindo consciências e instituições, atraindo o interesse de muitas pessoas, contribuindo para o desenvolvimento social do país, constituindo um ponto firme para a retomada da democracia após o período sombrio da ditadura militar. Por causa do seu compromisso religioso, social e político, ele foi hostilizado dentro e fora da Igreja. Em alguns ambientes, era considerado como um bispo "subversivo e extremista", "impertinente e incômodo", cujo magistério "era perigoso por estar embebido demais na teologia da libertação”. A vocação evangélica de Dom Casaldáliga, totalmente voltada aos últimos e aos esquecidos, logo foi reconduzida a essa leitura "subversiva" e "revolucionária" da teologia da libertação, uma interpretação redutiva e filha de uma profunda incompreensão e oposição àquela que foi a verdadeira missão de Dom Pedro (GAGLIANO, 2019, s.p).

Toda perspectiva de luta e enfrentamento a mazelas sociais as CEBs vêm traçando estratégias de resistências, nas configurações atuais, a partir de debates e resistências na defesa dos territórios ameaçados pelo capitalismo. As CEB's, no Baixo Tocantins, seguem essa lógica, em especial a Paróquia Nossa Senhora Rainha da Paz (Paróquia das ilhas de Abaetetuba, Pará), mediante ações de resistências nos territórios ribeirinhos e quilombolas.

\section{"Quando a Igreja anda sobre as águas": a atuação da paróquia das ilhas no município de Abaetetuba - PA}

A literatura sobre os confrontos políticos releva uma ampla diversidade de origens e o envolvimento de expressivos sujeitos e instituições. Dentre eles, destacamos que as igrejas são instituições curiosas e dúbias, porque sua própria estrutura representa um mosaico de correntes e disputas. Em outras palavras, podemos dizer que suas correntes expressam uma baila entre as hegemonias e contrahegemonias e cujos 
desdobramentos se apresentam de modo desigual em diferentes espaços. Frente a esta realidade, destacamos, neste tópico, o caso do município de Abaetetuba, por considerarmos um exemplo de vínculo com os sujeitos das classes populares e cujo fito, fora de organizar a população para alçar direitos, embora em menor expressão, é organizar pautas contrahegemônicas.

O município de Abaetetuba encontra-se localizado no Baixo Tocantins, nas regiões intermediária de Belém e imediata de Abaetetuba (IBGE, 2017). Sua população é estimada em 156.292 pessoas (com base o ano de 2018), em uma área de $1.610,404 \mathrm{~km}^{2}$. Abaetetuba ainda possui proximidade territorial com os municípios de Barcarena, Ponta de Pedras, Muaná. O município é compreendido por uma expressiva diversidade (marcadas por saberes, memórias, usos e costumes, fazeres, simbologias) e fortemente relacionada à dinâmica dos rios (POJO; ELIAS, 2018), do qual populações tradicionais de Abaetetuba "convivem com costumes e uma rotina entrelaçada com os espaços dos rios, das matas, por áreas de várzea e de praia; contextos que apresentam especificidades ambientais e sociais, além da estreita ordem econômica" (POJO; ELIAS, 2018, p. 30) e "a temporalidade e territorialidade das águas têm um sentido muito mais simbólico, tidas como um bem da natureza e um elemento que integra grande parte das ações cotidianas, ao passo que as sociedades urbanas conferem às águas um status de recurso ou bem de consumo" (POJO; ELIAS, 2018, p. 31).

Segundo Coutinho (2018, p. 34), possui uma "região das ilhas":

[...] está localizada na confluência dos rios Tocantins e Pará. A região insular de Abaetetuba, onde residem os ribeirinhos do município, composta de 73 ilhas, é banhada pelo rio Pará, em sua face oposta à orla localizada na sede municipal, a partir de onde é possível desembarcar na área urbana de Abaetetuba e em outras comunidades ribeirinhas localizadas nos rios Guajará de Beja e Abaeté. É deste último que se originou o nome do município.

Apesar de Coutinho (2018) apresentar a totalidade de 73 ilhas, a paróquia aponta, em seus cadastros, 72. Estas representam um mosaico territorial que também constituiriam uma miscelânea de territorialidades de ribeirinhos e quilombolas. Ademais, é fundamental destacar que, formalmente, encontram-se organizadas enquanto Projeto de Assentamento Agroextrativistas (PAE), implantado pelo INCRA, conforme observado no mapa 1. No entanto, desse total, 16 possuem a jurisdição do Instituto de Terras do Estado do Pará (ITERPA) ${ }^{6}$, por serem comunidades Quilombolas. 
Figura 1: Mapa de localização das ilhas do município de Abaetetuba-PA com os assentamentos.

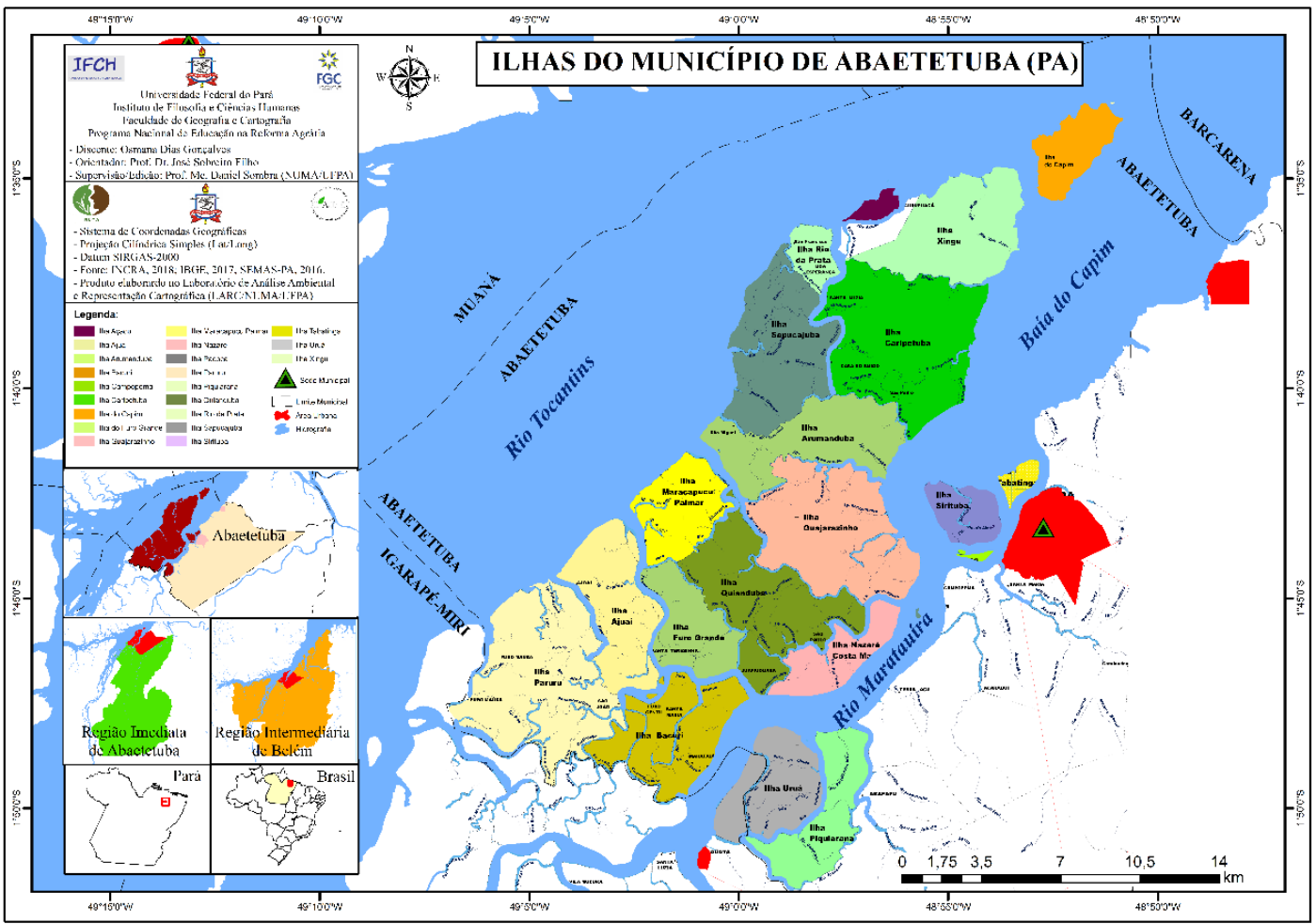

O mapa 1 apresenta os PAEs nos quais que a região insular do município é caracterizada, podendo ser identificados alguns rios que apresentam maiores dimensões. Os outros que não aparecem são caracterizados como pequenos rios e/ou igarapés. É no âmbito desse mosaico que a Paróquia das ilhas inicia, na década de 1980, suas ações. Sua origem tivera como base as CEBs, porém sua institucionalização como paróquia ocorreu em 8 de setembro de 1987, pelo Bispo diocesano Dom Ângelo Frosi. Nesse período, o pároco fora o padre José Buorghese. Antes da institucionalização, essas comunidades já vinham sendo acompanhadas pelos padres Xaverianos desde 1960.

O processo de organização das CEBs decorreu da ação eclesial de evangelização ligada à "ação preferencial pelos pobres" e em sintonia com a Teologia da Libertação, pautada na inseparabilidade entre fé e vida. Essa visão e ação eclesial de evangelização tornou-se muito forte, sobretudo, a partir da assistência do padre José Buorghese, que localmente era reconhecido como um sujeito que possuía um olhar sensível às necessidades do povo. Esse padre fora fundamental na formação de lideranças com esse mesmo olhar, capazes de estabelecer diálogo, de ouvir, sentir, estar junto e refletir sobre os descasos com os seus direitos. Em entrevista, a professora e assistente social Antônia Botelho, que também atua como agente pastoral da Paróquia das ilhas, aponta:

Aí vai se cutucar a questão da moradia, pensando em batalhar por moradia, depois, a questão da comida [...] Aí a gente vai sentindo a necessidade de outras questões: saúde, educação, da melhoria de vida do povo. E nas homilias das missas, eu acompanhei muito porque era da equipe paroquial, nas homilias a gente via assim, as homilias voltadas para a vida. E o padre José sempre buscava esse Evangelho que você tá vivendo, aí ele foi animando a gente. Até a gente que tava morando alí, ainda não tinha se dado conta. É mesmo, você não tem isso, não tem aquilo, você não tem esse direito, nem a gente tinha compreensão desse direito. Foi despertando a gente pra isso aí vieram os grandes cursos de formação, ele investia muito na formação. 
Diante dessa dura realidade, houve a necessidade de criar uma entidade que representasse essas comunidades. Então, em 1986, um ano antes de se institucionalizar a Paróquia das ilhas, foi criada a Associação dos Moradores das Ilhas de Abaetetuba (AMIA). Ademais, fora por meio das lutas que muitos direitos foram garantidos:

\begin{abstract}
Aí nós fomos lutando e fomos conseguindo o que a gente tem no mundo social. Se hoje você não tem professores analfabetos, graças à Paróquia das ilhas e à Associação dos Moradores das Ilhas de Abaetetuba. Se foram contratados os primeiros 25 agentes de saúde, graças essas duas instituições (Antônia Botelho, agente pastoral da Paróquia das ilhas, entrevista realizada em 08 de fevereiro de 2019).
\end{abstract}

Esse resgate histórico nos permite compreender a herança políticoorganizacional deixada para a comunidade, a AMIA e a paróquia. No entanto, a luta é contínua pelos muitos direitos que ainda são negados. No âmbito econômico, as comunidades passaram a se organizar buscando nas formas de solidariedade um espaço de vivências comunitárias. Desse processo surgiram as cantinas comunitárias e o cantinão $^{7}$, as estações de psiculturas que abasteciam os lagos menores e, ao mesmo tempo, repovoavam os rios de peixes, sendo, então, uma prática de "bem viver, de ideia, de pastoralidade e transformação social" (Antônia Botelho, entrevista realizada em 08 de fevereiro de 2019).

\title{
Quando o território ribeirinho resiste ao agronegócio nos rios: a disputa territorial e as práticas de resistência ribeirinha frente à Cargill
}

Os conflitos de interesses e convergências de pautas de movimentos socioterritoriais de Abaetetuba constituem componente histórico de dissensões. Divergências que vêm dando origem a organizações, mobilizações e estratégias de lutas frente à territorialização de agentes econômicos como, por exemplo, sobre a Cargill. Esta possui um grande projeto portuário na ilha Xingu, referente à construção de um Terminal de Uso Privado ${ }^{8}$ (TUP Abaetetuba), orçado em aproximadamente 900 milhões de reais.

A intenção da Cargill é que o porto esteja operando a partir de 2021, sendo a última fase do empreendimento a ser construído até 2030, com a pretensão de receber barcaças vindas do porto de Miritituba-Itaituba (PA) e Porto Velho (RO). Essas barcaças virão por trechos dos rios Tocantins, Amazonas, Madeira e Tapajós, e serão armazenados os produtos, posteriormente exportados em navios. O projeto pensado para Abaetetuba refere-se ao escoamento de produtos do agronegócio, principalmente commodities agrícolas, e será uma forma de encurtamento com o mercado internacional (EUA e China), com a criação de uma rede global de financeirização e da cadeia de commodities, bem como de uma fonte de investimentos especulativos de bancos e fundos de investimentos (RODRIGUES, 2018a).

Esse foco de atenção e mudança no eixo - corredor de exportação de grãos- que antes tinha a região sudeste como protagonista nessa dinâmica, nos dias atuais a região norte vem sendo pauta de discussões e planejamentos para facilitar esse processo de escoamento de produtos do agronegócio. Fica destacado no Estudo de Impacto Ambiental e no Relatório de Impacto Ambiental (EIA/RIMA) da Cargill (EIA/RIMA, 2018), elaborado pela Ambientare Soluções Ambientais $\operatorname{LTDA}^{9}$ (2018, p. 11) a mudança escoamento de produtos do agronegócio para o eixo norte do Brasil: 
Desde meados da década de noventa, com o estabelecimento dos terminais da Hermasa Navegação, em Itacoatiara -AM e da Cargill Agrícola, em Santarém-PA, ficou claro que a maneira mais econômica de transporte de granéis vegetais oriundos dos estados do Pará, Maranhão, Piauí, Tocantins, Rondônia e Mato Grosso para o mercado internacional é através da região norte.

Estrategicamente, esses grandes projetos tem sido pensados para o Norte do Brasil, sendo que estão planejados mais 96 portos graneleiros para região. Deste total, Itaituba soma mais de 30 (RODRIGUES, 2018a) e o complexo de BarcarenaAbaetetuba, mais de 16 (RODRIGUES; RODRIGUES; LIMA, 2019). Projetos que não têm levado em consideração os povos que ali vivem, assim como seus modos tradicionais e suas territorialidades. Violam direitos humanos desses povos, os quais, muitas vezes, sequer são consultados, conforme determina a Convenção 169. Via de regra, são projetos movidos pelo intenso processo de financeirização promovido pela consolidação e expansão da razão neoliberal, da qual vem encontrando apoio, legitimação, financiamento, subsídios e concessões de terras de governos.

Tanto o Estado como as grandes empresas afinam o discurso de que esses grandes projetos têm como finalidade o desenvolvimento territorial, consequentemente a melhoria econômica e social da população local. Porém, na prática histórica de políticas e projetos para Amazônia, e recentemente materializada, por meio de complexos portuários em operação em Itaituba (Cargill, Unitapajós, Cianport, Hidrovias do Brasil, Transporte Bertolini) e Barcarena (Unitapajós, ADM, Hidrovias do Brasil), vê-se a expansão da concentração de renda, terras e moradias e "nenhum" apoio (significativo) ou mudança estrutural para a agricultura familiar.

Carvalho (2012) realiza uma contundente argumentação, sobre essa questão, ao enfatizar que nenhuma das políticas de desenvolvimento "serão verdadeiramente justas e democráticas sem a efetiva participação de indígenas, ribeirinhos, mulheres, remanescentes de quilombos, extrativistas e agricultores familiares/camponeses" (CARVALHO, 2012, p. 14). Participação efetiva do qual destaca Carvalho (2012) vem sendo injustas, antidemocráticas e invisibilizadora das populações tradicionais, e expresso no EIA/RIMA do porto da Cargill, por exemplo, quando menciona que o porto só "interferir" apenas uma comunidade quilombola (Nossa Senhora do Bom Remédio), ou seja, não levam em consideração também as comunidades tradicionais ribeirinhas.

O EIA/RIMA do porto da Cargill não levam também em consideração seus modos de vida, o direito de permanecer nos seus territórios, mas os expulsam lentamente e os consideram como estrangeiros, bloqueadores do progresso, empecilho ao desenvolvimento local e regional. Como aduz Carvalho (2012): "Imagine proibir pessoas que sempre se utilizaram do rio para pescar e se alimentar, se locomover, transportar mercadorias e para os seus rituais de repente virem-se proibidas de acessá-lo para capturar peixes, por exemplo" (CARVALHO, 2012 p. 10).

Já não é o pescador que escolhe onde executar sua atividade, mas as lógicas capitalistas que o empurram para mais longe de seu território, para uma possível escassez de áreas de pesca. Para o ribeirinho, como sobreviver sem o peixe e sem os recursos que a natureza possibilita? Como firmar sua identidade em um território que se encontra ameaçado de lhe pertencer? Qual é a angústia e dor pela insegurança e desproteção social? Segundo Castro (2017. p. 33), movidos por uma lógica do grande capital de que:

Os rios da Amazônia tornaram-se um novo espaço de interesse de mercado, seja de empresas de mineração, do agronegócio, de transporte de cargas ou de 
uma série de outras atividades empresariais mobilizadas pelas grandes obras de infraestrutura, entre elas, com destaque, os terminais portuários.

Seria a lógica de mercado, que transforma os rios em "corredores de exportação" (CASTRO, 2017, p. 25). Nessa percepção, o rio não é vida, mas apenas uma rota de escoamento, que nessas rebeldias vai mudando sua dinâmica de existência para resistência. As CEBs, já na década de 1980, mesmo desconhecendo as ameaças que poderiam estar mais próximas de seus territórios, cantavam músicas escritas, a partir da realidade, diante da implantação da Albrás/Alunorte, em Barcarena, mas que já sentiam o "progresso" chegando.

Cantamos nossa realidade, com nossas autorias: "Beira das ilhas, beira do meu coração"; "Lá vai a paca, a cutia e o arapuã", todas autorias do Rai Borges. Tudo o que o Rai cantou nesse canto, a gente tá vivendo hoje com a chegada da Cargill. No Grito das Águas eu lembrei do Rai Borges e coloquei lá. Tem uma estrofe que diz que o capital chega, ele não pede licença. Ele envenena a tua água e o teu ar, polui o teu ar né, e expulsa todo mundo, inclusive os animais, quando ele diz: "Quero ver a onça. Só se for pintada! Quero ver coruja. Só embalsamada! E cadê a bicharada? Tá fugindo da queimada." Tá sendo expulsa! A mesma coisa o açaí. "Pra onde vai nossos peixes?" Essa música contava o que naquela época a gente já tinha medo do que poderia chegar. E a gente cantava ali, baseado na Albrás. A Albrás despertou a gente: "Pra onde vai a paca?" A Albrás que despertou a gente para o "Brega ecológico", né, do açaí, foi a Albrás. (Antônia Botelho, agente pastoral da Paróquia das ilhas, entrevista realizada em 08 de fevereiro de 2019).

No entanto, naquela época, a CEB's sentiram dificuldades nas articulações de lutas e resistências sobre a implantação da Albrás/Alunorte. A Paróquia das ilhas se organizou e foi para as ruas reivindicar, porém, Barcarena, sendo o município que iria receber o empreendimento, não se uniu à luta. Até mesmo os que se encontravam a favor do empreendimento criticavam os padres xaverianos da época, "em muitos lugares e assembleias, a população pegar o microfone e dizer: 'Você [para os padres xaverianos] é contra porque você é estrangeiro. Na frente do padre que tá te defendendo, entendeu? " (Antônia Botelho, agente pastoral da Paróquia das ilhas, entrevista realizada em 08 de fevereiro de 2019).

Assim, depois que a Cargill divulgou o projeto portuário em Abaetetuba houve a construção da narrativa de que a área teria petróleo, no caso estocaria combustível. Isso incentivou a comunidade a se organizar e, nesse contexto, foi organizada resistência com base na cartografia social ${ }^{10}$. Essa foi uma maneira que a comunidade encontrou para resistir, estabelecendo sua própria cartografia, apontando os limites e os modos de organizações vividas. Porém, mesmo antes da Cargill, a Ilha do Capim já despertava o interesse do capital, como sendo uma área para possíveis projetos, mediante o processo da instalação da Hydro ${ }^{11}$.

Atualmente esse discurso de possíveis perspectivas de que possa ser encontrado petróleo continua na Ilha Xingu, onde a Cargill pretende firmar seu projeto. Trata-se de uma maneira de persuadir os povos que ali vivem e uma forma de flexibilizar a entrada do capital nesses territórios. O processo de resistência das CEBs face à implantação da Cargill tem como ponto de partida o momento que a Paróquia das ilhas teve conhecimento do projeto, em 2016, por meio da vinculação em jornais e rádios locais.

No segundo semestre de 2017, a paróquia promoveu, em dois dias, um estudo sobre a Convenção 169, tendo a presença do Núcleo de Defesa dos Direitos Humanos $(\mathrm{NDDH})^{12}$ e da Federação de Órgãos para Assistência Social e Educacional (FASE). Esse curso teve, em sua maioria, a presença de lideranças comunitárias. Tendo como 
ação concreta a criação de uma equipe para reprodução desse mesmo curso, nas comunidades consideradas como área de maior risco em face da instalação da Cargill.

Assim, o próximo passo foi descer para a base, sendo que o objetivo da equipe foi reproduzir o curso e formar uma comissão em cada uma dessas comunidades, envolvendo representantes de entidades, organizações e igrejas para organização junto com a comunidade do protocolo de consulta.

Figura 2: Mapa das comunidades onde foi realizado o curso sobre a Convenção 169.

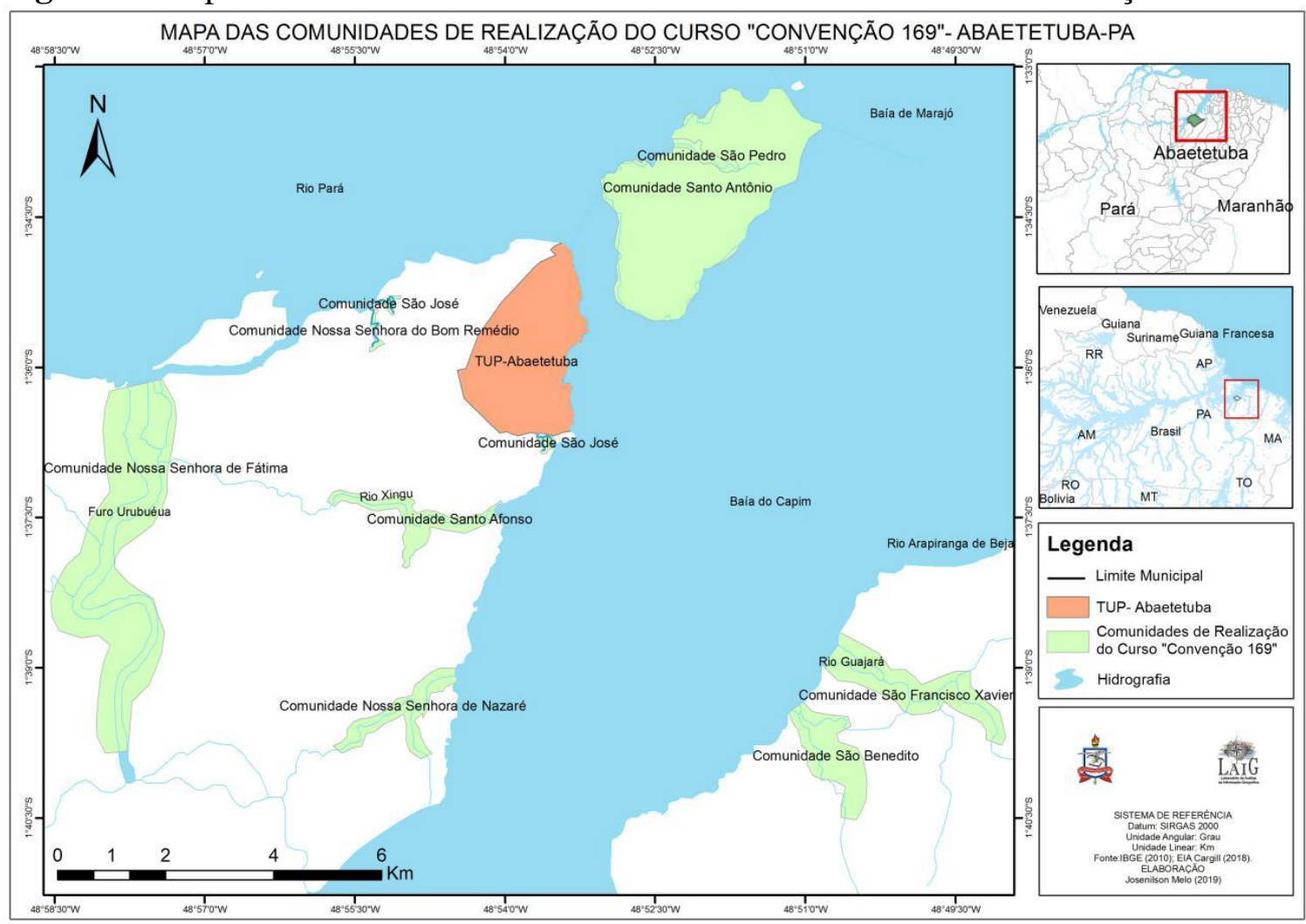

Observa-se, no mapa, que ocorreu número significativo de ações de instrumentalização e formação das populações tradicionais, acerca do curso sobre a Convenção 169 promovido pela paróquia das ilhas, como mecanismo de organização para políticas em resistência frente ao projeto TUP-Abaetetuba, da Cargill. Essas ações possibilitam a luta pelo reconhecimento, respeito e autonomia, pelo pluralismo/identidade/liberdades expressivas "condições sociais, culturais e econômicas os distingam de outros setores da coletividade nacional, e que estejam regidos, total ou parcialmente, por seus próprios costumes ou tradições ou por legislação especial" (Artigo $1^{\circ}, \S 1$, Convenção 169), já que possuem organização social, política e cultural distintas da sociedade de grande formato (DUPRAT, 2014).

A convenção 169 contribui para "mostrar", "incentivar" ou "evidenciar" populações que possuem diferenças, especificidades, singularidades, territorialidades e relações ontológicas, cosmológicas, com dimensões de vida indissociáveis entre rio, plantas, animais, florestas e suas culturas, consequentemente, o que contribui para reprodução social, material e da(s) sua(s) identidade(s). Além disso, a convenção adiciona nas disputas territoriais um fragmento que mostra a não-tutela desses povos ao Estado, que é o: "Artigo $7^{\circ}, \S 1$. Os povos interessados deverão ter o direito de escolher suas, próprias prioridades no que diz respeito ao processo de desenvolvimento, na medida em que ele afete as suas vidas, crenças, instituições e bem-estar espiritual, bem 
como as terras que ocupam ou utilizam de alguma forma, e de controlar, na medida do possível, o seu próprio desenvolvimento econômico, social e cultural. Além disso, esses povos deverão participar da formulação, aplicação e avaliação dos planos e programas de desenvolvimento nacional e regional suscetíveis de afetá-los diretamente".

Para Fernandes (2013a), os seres humanos necessitam construir espaços e territórios que garantam sua existência, para isso (disputam):

[...] sujetos utilizan sus intencionalidades creando, construyendo, produciendo sus significaciones de conceptos, sus interpretaciones y sus «enfoques» de realidades, evidenciando aspectos de acuerdo con sus intereses, definiendo sus espacios y sus territorios, concretos y abstractos, materiales e inmateriale (FERNANDES, 2013a, p. 119).

Por fim, a convenção possibilita reforçar a liberdade expressiva dos povos tradicionais -inviabilizada normativamente até então - sem presença na arena pública e sem qualquer aporte as suas especificidades nos debates nacionais (DUPRAT, 2014); sem questionar e decolonalizar todo o instrumental homogeneizante de ver as populações. Estas "vistas" por classificações totalizantes, asfixiadoras "territorialidades específicas" e narrativas discursivas em torno da incompetência e impossibilidade de falar e gerir a vida, o que alimentou um sistema de poder opressor, excludente, espoliativo, colonialista e de superioridade de saber.

As formações nas comunidades que "vivem próximas" ao projeto de porto da Cargill seriam uma forma de instrumentalizar lutas/disputas e criar contranarrativas aos processos e imaginários de superioridade, progresso e desenvolvimento que esse empreendimento traria. Após o curso de convenção 169, foi formada uma comissão comunitária de defesa do território. Comissão essa que preparou ofícios, os quais foram encaminhados pela Paróquia à defensoria pública, solicitando o acompanhamento do Núcleo de Defesa dos Direitos Humanos (NDDH). Além disso, ajudou na agilização do processo de organização do protocolo de consulta em três comunidades.

No início do ano de 2018, mediante a organização da Paróquia das Ilhas, a Diocese de Abaetetuba se reuniu para fazer a discussão acerca dos territórios ameaçados pelo agronegócio, pois, como enfatiza Fernandes (2013b, p. 201), mediante as contradições do capitalismo, torna-se necessário para o enfrentamento a "necessidade do debate constante, nos planos teóricos e práticos, a respeito do controle político produzindo espaços e territórios heterogêneos". Então, o intuito foi fortalecer esse campo de resistência, do qual se discutiu o encaminhamento de criação de uma comissão diocesana de enfrentamento aos grandes projetos. A partir dessa organização criou-se a comissão ribeirinha de enfrentamento aos grandes projetos. Diante dessas estratégias de enfrentamento, ocorreram perseguições políticas, principalmente a quem se encontrava assessorando essas ações.

No dia 22 de março de 2018, Dia Mundial da Água, a Paróquia promoveu uma grande manifestação denominada "Grito das Águas" (Figura 3), realizada em frente à Ilha do Capim, denominado de Areia, fronteira com o terreno da Cargill. Essa manifestação representou uma grande marca na resistência de luta pelo território de vida, do qual reuniu pessoas de diferentes idades e das diversas comunidades; além de diversos movimentos (pastorais, Comissão Diocesana e Ribeirinha de enfrentamento aos grandes projetos), instituições (Cáritas diocesana Dom Ângelo Frosi, Cáritas Paróquia das Ilhas, Igrejas, escolas, Universidade Federal do Pará, AMIA, colônia dos pescadores, rede de comunicação-rádio Conceição) e parceiros da luta pelos direitos dos povos tradicionais. 


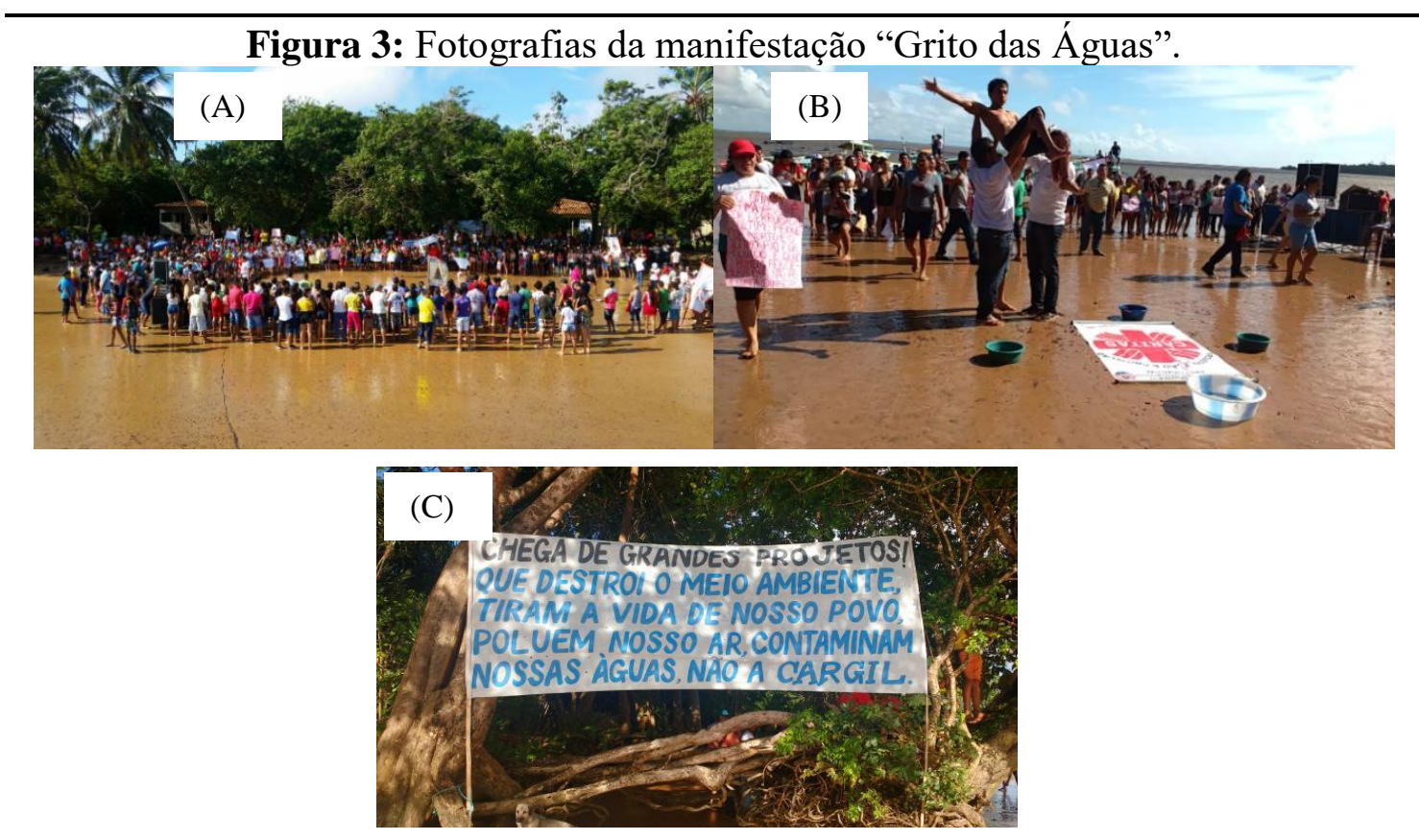

Fonte: Foto (A) Pacheco, 2018. Foto (B e C) de Osmana Gonçalves.

Essa manifestação foi à representação da grande indignação das comunidades, que expressavam suas revoltas por meio de faixas, cartazes, místicas, músicas, apresentações e palavras de ordem. $\mathrm{Na}$ manifestação, era expresso o território de "dominância "funcional" (HAESBAERT, 2007), como recurso, valor de troca pelos grandes agentes capitalistas (a Cargill), território como símbolo, valor simbólico ("abrigo", "lar", segurança afetiva e fonte de vida e de existência e reprodução social). A manifestação era o enfrentamento e a "disputa pela vida", já que para esses povos o território não possui valor de troca, não possui um valor material financeiro.

Disputas também foram travadas com Estado, devido regularizar terras, emitir licenças e isentar impostos, conceder incentivos fiscais, arrendar áreas e/ou privatizar propriedades públicas. Esse posicionamento do Estado é expresso na área do projeto portuário da Cargill, na Ilha Xingu, do qual área foi regularizada e transferida à multinacional. Cabe destacar que o terreno está localizado em área de assentamento, terra da união.

Nesse processo de favorecimento à dinâmica capitalista, desencadeiam-se a especulação de terras e conflitos/conflitualidades, renegando o direito coletivo que esses povos têm sobre o território. Logo, dialogando com Rodrigues (2012 e 2018a), esse fato constitui um processo de mercadorização e financerização de terras e territórios, como sendo uma privatização de direitos e certidão concedida pelo Estado para desmatar, explorar, poluir, expulsar e violentar direitos humanos e étnicos.

No enfrentamento a tudo isso, a Paróaquia organizou o "Grito das Águas", nos dias 06 e 07 de setembro de 2018, o qual foi antecedido pelo "Pré Grito" e o "Grito dos Excluídos e Excluídas", como forma de debater e expor violências e violações dos grandes projetos que ameaçam a vida do povo ribeirinho e quilombola. O "Pré Grito" foi realizado no dia 06, o dia todo, no centro pastoral da paróquia. Buscou traçar uma linha de debate sobre as ameaças que se encontram nesses territórios, na perspectiva dos grandes projetos pensados para Amazônia; tendo como parceiro e facilitador nessa discussão a FASE. Teve como parceira e facilitadora, nessa discussão, a FASE. O debate continuou à noite, por meio de uma roda de conversa que envolveu também o público da cidade, fazendo uma análise sobre os grandes projetos pensados para Abaetetuba. 
A culminância de todo esse debate foi no dia 7 de setembro de 2018, no Grito dos Excluídos (figura 4), o qual reuniu um número significativo de pessoas vindas das diversas comunidades e se unindo com os moradores da cidade para, juntos, fazer ressoar pelas ruas o "grito" de indignação e de resistência; assim como chamar atenção das autoridades, principalmente, do poder executivo municipal de que os direitos das pessoas precisam ser respeitados.

Figura 4: Grito dos/as Excluídos e Excluídas 2018

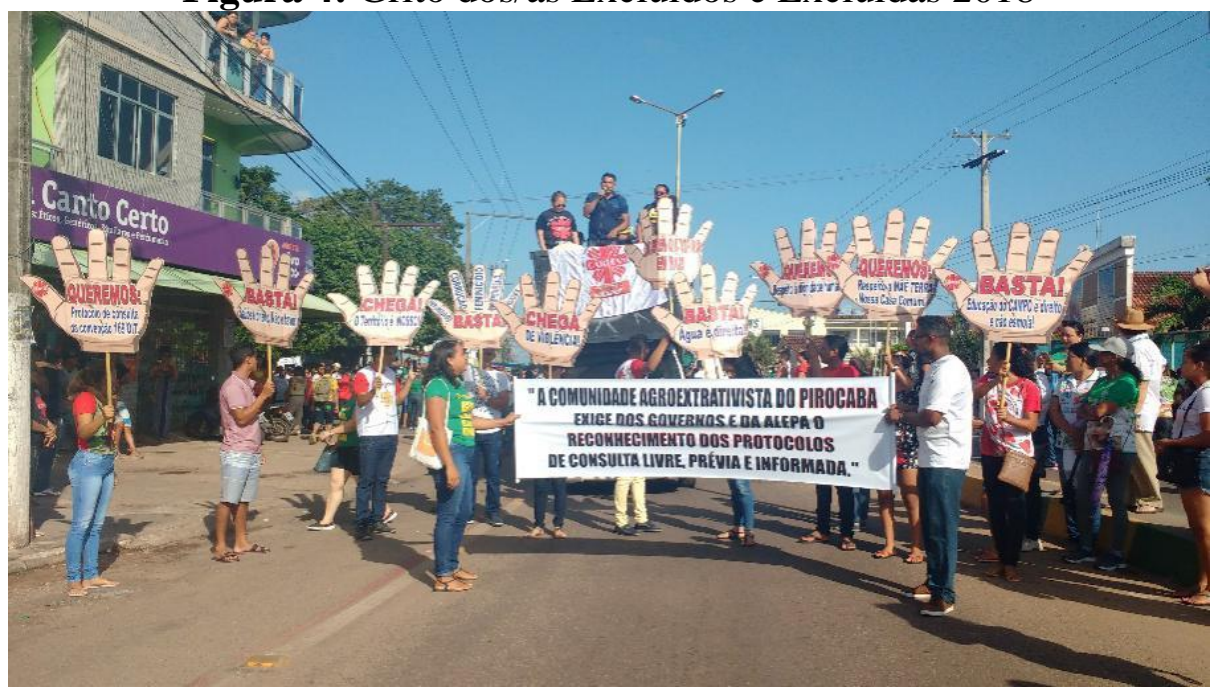

Fonte: Foto de Osmana Gonçalves.

Esse ato foi realizado com o percurso pelas principais ruas da cidade, e uma concentração final na Praça da Igreja matriz de Abaetetuba, denominada Nossa Senhora de Conceição. Toda essa movimentação ocorreu com muitas representações visuais (faixas, banner, cartazes), carro-som, que alternava com músicas que expressavam a luta, resistência; com falas de entidades e lideranças comunitárias.

O Grito dos excluídos e excluídas já está em sua $24^{\circ}$ edição, sendo um ato nacional motivado pelo descontentamento do povo face às diversas negações de direitos. Cada edição é motivada por um tema. Neste ano de 2018, o Grito se baseou no tema: "Desigualdade gera violência: basta de privilégios!", e o lema "Vida em primeiro lugar!”. Diante das várias negações de direitos, a Paróquia das Ilhas também traz o "grito" das ameaças que esses povos vêm sofrendo em seus territórios, motivadas por lógicas e tempos diferentes à região, com a perspectiva compreensiva de que o território é "unifuncional" (HAESBAERT, 2007), utilitarista, proposto e reproduzido pela lógica capitalista hegemônica e com valor de troca. Compreensão essa que espraia em processos de dominação e/ou de apropriação sociedade-espaço, da supressão ou dominação político-econômica, "eliminações" ou fragmentações de subjetividades, identidades, crenças, relações comunitárias (pautadas da cooperação e reciprocidade), relações de pertenciamento com lugar e o "sistema cultural-simbólico".

Ainda em 2018, no dia 16 de outubro, ocorreu uma audiência pública na câmara legislativa de Abaetetuba para tratar sobre o projeto portuário da Cargill. Novamente a Paróquia das Ilhas mobilizou as comunidades para participarem e organizou um ato nas ruas, antes da audiência. Mediante cartazes, faixas, instrumentos de trabalho utilizados pelas comunidades, carro-som, os ribeirinhos e quilombolas se expressaram, pelas ruas a caminho da câmara, a indignação e revolta de não terem seus direitos respeitados, e particularmente, terem sofrido violações de direitos humanos, étnicos e territoriais por grandes agentes econômicos, com a anuência (apoio, aliança e legitimação) do Estado. 
A audiência foi caracterizada por clima de grande indignação, tanto expresso nos cartazes como pelo coro que ressoava "Fora Cargill! Fora Cargill!". Apresentavam-se, em clima de revolta, mediante a mínima representação dos vereadores e a ausência do prefeito municipal. Por parte da empresa, estavam presentes apenas o instituto Peabiru (Ong financiada pela Cargill para construir o processo de legitimação social) e a Ambientare Soluções Ambientais LTDA. Esta última empresa, contratada pela Cargill para realizar o EIA/RIMA, não tinha presente nenhuma representação direta da empresa Cargill.

Figura 5: Audiência pública sobre o porto da Cargill, na câmara legislativa de Abaetetuba, no dia 16/10/18.

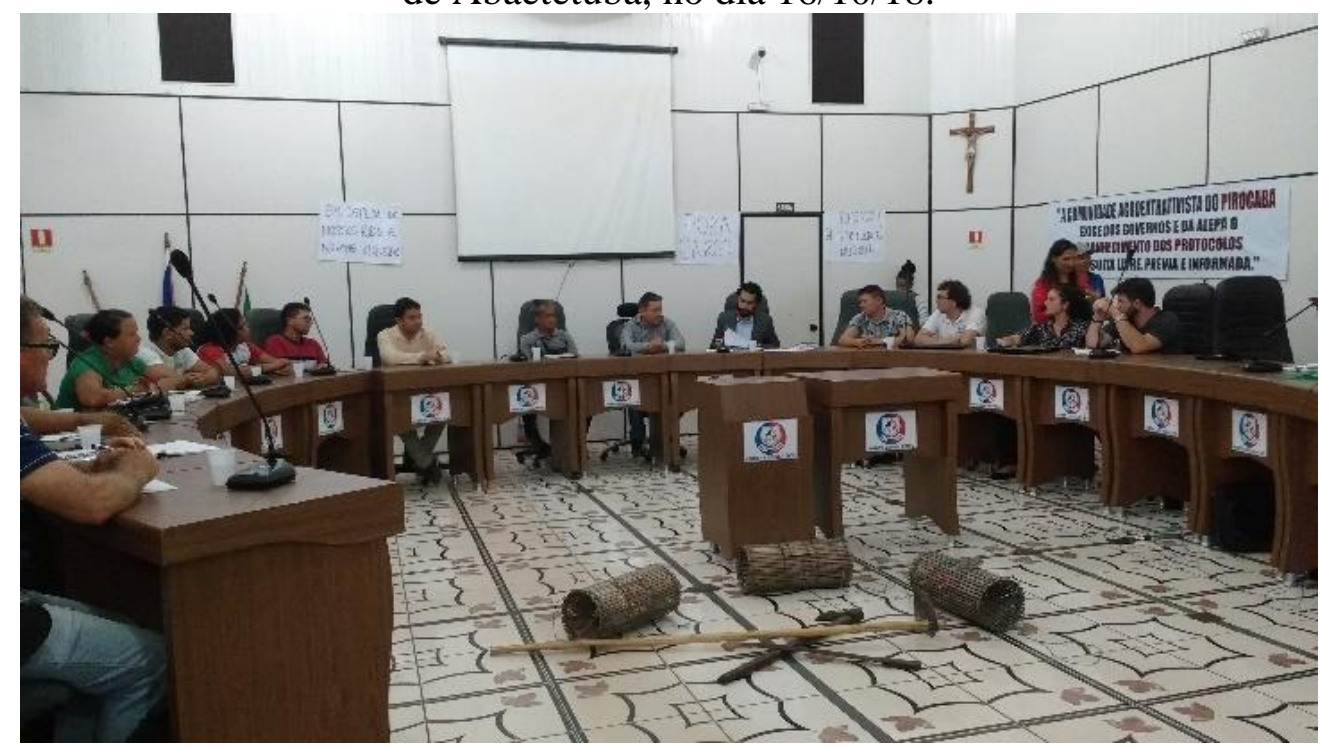

Fonte: Foto de Osmana Gonçalves.

A ausência da própria empresa e do poder executivo municipal resultou em poucos êxitos, no que tange à abertura de debates com as comunidades tradicionais. Por conseguinte, os povos das comunidades não tiveram nenhuma resposta dessas duas organizações, intensificando ainda mais a indignação já existente, mediante a ausência de informações. Essas ausências de diálogos e a própria falta de transparência do poder executivo municipal geraram desconfortos na população. Também, a própria negação da Consulta Livre, Prévia e Informada, conforme descrito na Convenção 169, que essas comunidades têm exigido do governo, mas que não foram atendidas. Até mesmo a possibilidade de acesso ao Plano Diretor Municipal à população é ignorada, sendo um documento público, porém negado.

As principais ações de estratégias políticas de enfrentamento aos grandes projetos, já descritas acima, e o período que foram realizadas, as quais foram executadas ou apoiadas pela Paróquia das Ilhas, são explicitadas no quadro abaixo: 
Quadro 1: Principais ações políticas de enfrentamento ao Projeto TUP-Abaetetuba da Cargill, realizadas ou apoiadas pela Paróquia das Ilhas.

\begin{tabular}{|l|l|}
\hline Atividades & Período de realização \\
\hline 1) Curso sobre a Convenção 169 2017 \\
\hline $\begin{array}{l}\text { 2) Reprodução do curso sobre a Convenção 169, nas } \\
\text { comunidades de risco }\end{array}$ & 13 a 21 de dezembro de 2017 \\
\hline $\begin{array}{l}\text { 3) Preparação e envios de ofícios solicitando o } \\
\text { acompanhamento do NDDH- Defensoria Pública }\end{array}$ & Janeiro de 2018 \\
\hline $\begin{array}{l}\text { 4) Criação da Comissão Diocesana de enfrentamento } \\
\text { aos grandes projetos e da Comissão ribeirinha de } \\
\text { enfrentamento aos grandes projetos }\end{array}$ & Fevereiro de 2018 \\
\hline 5) Manifestação "Grito das Águas" & 22 de março de 2018 \\
\hline 6) Pré Grito e Grito dos/as Excluídos e Excluídas & 06 e 07 de setembro de 2018 \\
\hline 7) Audiência pública na Câmara Legislativa de & 16 de outubro de 2018 \\
Abaetetuba & \\
\hline
\end{tabular}

Fonte: Elaborado por Osmana Gonçalves a partir de entrevista realizada no dia 08 de fevereiro de 2019.

As atividades descritas e apresentadas no quadro fazem parte das principais ações que a Paróquia já realizou desde que tomou conhecimento sobre a possível instalação do porto da Cargill, na Ilha Xingu. No entanto, vê-se que a luta vai se tornando cada vez mais desafiadora, pois as estratégias de articulação de resistências e enfrentamento ainda se percebem enfraquecidas. Isso ocorre porque o capital também se articula, cria brechas, dissensões, cooptações (SOBREIRO-FILHO, 2015b) e, enquanto os movimentos buscam se mobilizar, ele se fortalece por meio da desmobilização desses movimentos. E assim surgem os desafios no campo de resistência:

Uma primeira dificuldade é justamente o poder financeiro diante da pobreza. O poder financeiro diante da ignorância pela falta de conhecimento. O poder financeiro que faz a cooptação de lideranças. Nós temos lideranças cooptadas, né, dói na alma, mas é verdade. Cruel dizer isso, mas é o que eu percebo (Antônia Botelho, agente pastoral da Paróquia das ilhas, entrevista realizada em 08 de fevereiro de 2019).

Essas dificuldades vêm sendo enfrentadas pela Paróquia, no caso das CEB's, pois o capital apresenta suas seduções para alcançar seu interesse. Essas seduções se apresentam de diversas formas, como descrito acima, por meio de cooptação e dissidência, particularmente via poder compensatório, em que a submissão é recompensada, sobretudo, pecuniariamente (SOBREIRO-FILHO, 2015b); assim como pela criação de uma narrativa de: 1) gigantismo econômico e sua maneira benevolente; e, 2) única solução capaz de desenvolver a região e distribuir renda mediante ofertas de empregos (dispersos na construção de portos privados, na Amazônia, em Itaituba, Rurópolis, Barcarena/no estado do Pará) e Santana e Macapá (no estado do Amapá), porém, também inscritos em projetos portuários na região de Suape (estado de Pernambuco) e do Açu (estado do Rio de Janeiro).

A Cargill está tentando persuadir as comunidades com a proposta de empregos, como forma de criar discordâncias internas ou conflitos nas comunidades das ilhas, seja nas lideranças e movimentos socioterritoriais da "Amazônia Tocantina" (na Região de Abaetetuba), seja contribuindo ou esfacelando nas/as lutas territoriais e legitimação do projeto.

Tal lógica se deve ao fato de que as lutas sociais são vistas como empecilhos ou mesmo forças ameaçadoras. Como apresenta Carvalho (2012, p. 14): "São atores sociais 'perigosos' para o sistema", e assim afirma, "porque a sua própria existência (modos de vida e modos de pensar) se constitui numa afronta a um sistema que tem a 
capacidade de transformar tudo e todos em mercadoria”. É a percepção que o capital busca da pessoa humana, assim conseguindo forças para se perpetuar.

\section{Considerações finais}

A dinâmica de "ocupação" colonizador-espoliadora e a formação socioeconômica na Amazônia são marcadas por uma história calcada na exploração, perdas, danos e conflitos/conflitualidades. Acompanhados dessa dinâmica e formação socioeconômica, os processos econômicos, a expansão do mercado (circuito produtivo e financeiro) e a integração da Amazônia foram estabelecidos ou pavimentados frente às negações; por trata-se de projetos de colonialidade, despossessão, violências e violações de direitos dos povos originários. É formato de apropriação e de conflitualidades, multiplicadas e/ou repetidas, principalmente na "Latin American, like other regions of the Global South, is the epicentre of several mechanisms of capital territorialisation based on the dispossession of its commons" (RINCÕN; FERNANDES, 2018, p. 2085), porém, mais recentemente como uma agenda política, "consenso de commoditties", e um projeto Estado, notadamente do Estado brasileiro.

A Amazônia oriental, e mais recente a "Amazônia Tocantina", passam a constituir fonte das "assanhas" de processos espoliativos/despossessão e especulativos, isto é, processos expansivos de acumulação de capital, pautados no controle, extração de bens comuns, desterritorializações de comunidades rurais, como discorridos no artigo. Esse cenário constitui a privatização da terra e dos rios, a eliminação e violação dos direitos (humanos, étnicos e territoriais), e fonte de perdas ou destruição de existência materiais e imaterial (crenças, culturas e cosmologias); a supressão de formas "alternativas" de produção e usos dos territórios, por populações ribeirinhas e quilombolas.

No contexto dessa lógica conflituosa e de disputas territoriais, a mobilização dos movimentos socioterritoriais, como a CEB's (a paróquia Paróquia Nossa Senhora Rainha da Paz), vêm se tornando fundamentais para afirmação da soberania dos povos tradicionais em seus territórios; instigando as dimensões de solidariedade e comunitariedade, em tempos tão perversos ${ }^{13}$, individualistas, de fragmentação de vínculos sociais coletivos e afetivos.

Ao mesmo tempo se fertiliza atos políticos contrahegemônicos calcados no "ser" e na valorização da identidade tradicional, também dos valores de decrescimento como liberdade, sociabilidade e cuidado com o meio ambiente. Valores esses já imersos nas lógicas e dinâmicas cotidianas e reprodutivas de ribeirinhos, quilombolas e pescadores.

Por fim, evidenciar experiências de resistência que são pouco publicizadas, até mesmo por uma questão de estratégia de luta (e de não criminalização em face da expansão ultraconservadora e fascista que "retoca" e/ou tempera a política neoliberal financeirizada), são fundamentais para oxigenar em outros espaços-tempos e regiões mobilizações, organizações e estratégias de resistência, principalmente porque a Amazônia vive o fascismo e uma agenda ultraconservadora com um grau ainda mais elevado.

\section{Notas}

1 - A "palavra" progresso foi "convertido em expressão e em conceito equiva-lente de desenvolvimento material e de consumo individual crescentes, essa forma de desenvolvimento que procura imitar o dos países hegemônicos se apresenta para governantes, elites e amplos segmentos das sociedades ocidentais como a única via possível de alcançar o bem-estar social, o que, por sua vez, só a sociedade de consu-mo pode propiciar" (LOUREIRO, 2012, p. 528). 
2 - El neoextractivismo va más allá de la propiedad de los recursos, sean estatales o no, ya que termina reproduciendo la estructura y las reglas de funcionamiento de los procesos productivos capitalistas, volcados a la competitividad, la eficiencia, la maximización de la renta y la externalización de los impactos sociales y ambientales" (GUDYNAS, 2012, p. 132-3).

3 - Esse recorte temporal foi determinado com base ao período que a Paróquia das Ilhas toma propriedade sobre o projeto TUP-Abaetetuba da Cargill. E que a partir de 2017 vem desenvolvendo ações de cunho político de resistências nas comunidades.

4 - Segundo Sobreiro-Filho (2015a) enfatiza, a criação dos conceitos de movimento socioespacial e movimento socioterritorial é uma construção, cujo desdobramento direto perfaz-se de uma leitura cujo espaço é elemento fundante, ou seja, o ponto de partida para a análise geográfica sobre os movimentos. Justamente este ponto de partida torna-se o principal elemento na diferenciação do conceito de movimento social. $\mathrm{O}$ autor ainda assinala que os movimentos são produtores, construtores e transformadores diretos e indiretos do espaço material e imaterial. Assim, todo movimento socioterritorial é também um movimento socioespacial, mas nem todo movimento socioespacial é um movimento socioterritorial. A interação com espaço e, portanto, a compreensão da relação sujeito-espaço é ponto comum em ambos os conceitos. Contudo, além de ter os mesmos elementos que um movimento socioespacial possui, o movimento socioterritorial também agrega o território em sua essência, fato que o faz também muito complexo.

5 - Nascido na Catalunha, no dia 16 de fevereiro de 1928, durante 38 anos, viveu e trabalhou no Brasil; primeiro como missionário da Congregação dos Missionários Filhos do Coração Imaculado de Maria, ou Congregação Claretiana, depois como prelado de São Félix a partir 1971, ordenado bispo em outubro do mesmo ano por Paulo VI.

6 - O Instituto de Terras do Estado do Pará (ITERPA) foi criado em 08 de outubro de 1975, por meio da Lei $n^{\circ}$ 4.584. O objetivo, até então, era atuar na execução da política de preservação do patrimônio agrário paraense, além de promover o fim da insegurança dominial e a tão almejada paz no campo. Porém, sua atuação se foca em política de regularização fundiária como forma de: i) diminuir a violência rural; ii) assegurar o direito de propriedade aos diferentes segmentos sociais; iii)diminuir o desmatamento; e, iv) garantir a sustentabilidade ambiental. O Iterpa possui seis principais tipos de regularização fundiária, divididos em onerosa, não onerosa, Projetos Estaduais de Assentamento Sustentável (PEAS), Projeto de Assentamento Agroextrativista (PEAEX), Território Estadual Quilombola e Resgate Administrativo de Aforamentos.

7 - Grande comércio localizado no Rio Campopema, cuja mercadorias que se vendia eram compradas em Belém e do cantinão eram abastecidas as cantinas comunitárias, a um preço mais barato que na cidade. $\mathrm{E}$ como o cantinão era uma organização da Paróquia das ilhas, era uma forma também de conseguir lucro para sustentar a Igreja em suas obras sociais.

8 - Terminal de Uso Privativo (TUP) é a instalação construída ou a ser implantada por instituições privadas ou públicas, para a movimentação e armazenagem de mercadorias destinadas ao transporte aquaviário ou provenientes dele.

9 - Segundo Rodrigues (2018a, p, 277): “A empresa de consultoria dos Portos é Ambientare [em Itaituba e Rurópolis, Oeste do estado do Pará], com que além de responsável pelo EIA/RIMA (LDC, Cargill, Hidrovias do Brasil, CIANPORT, Bertolini, Odebrechet) de todos portos e que desenvolve políticas de responsabililidades social coportativa; Além das Pequenas Centrais Hidreléricas do Itapacurá/Itaituba e Cupari/Rurópolis".

10- Nos dias 22 e 23 de setembro de 2016, realizou-se oficina de mapeamento com os moradores da Ilha do Capim, situada no município de Abaetetuba. A atividade do Projeto Nova Cartografia Social da Amazônia ocorreu em parceria com estudantes do curso de Educação do Campo da Universidade Federal do Pará, campus Abaetetuba, com apoio do Programa de Extensão Universitária (ProExt) (NOVA CARTOGRAFIA SOCIAL DA AMAZÔNIA, 2016).

11 - Diante do movimento de resistência da Cargill, os moradores da Ilha, juntamente com a Paróquia, têm as informações de que a bacia de contenção de rejeitos da Hydro tinha como planejamento de instalação na Ilha do Capim. 
12 - O (NDDH) da Defensoria Pública do Estado do Pará tem a missão de garantir a promoção, proteção e defesa dos direitos humanos, oferecendo assistência jurídica integral aos legalmente necessitados, preferencialmente no âmbito coletivo.

13 - Tempos em que a globalização está se impondo como uma usina de produção de perversidades e contradições negativas, como desemprego, desmatamento, o aumento da pobreza e da desigualdade social, a emergências/intensificação de ("novas") enfermidades (ansiedade, depressão, suicídios, massacres em escolas), a mortalidade infantil e sub(des)nutrição), expulsão de terras e deslocamento forçados (promidos pelo Estado, por empresas ou por meio de alianças) desproteções sociais (previdenciária, de saúde pública, educação e de segurança pública) permanece, a educação de qualidade é cada vez mais inacessível. É uma globalização do qual o consumo é cada vez mais representado como fonte de felicidade e a perversidade sistêmica está relacionada à adesão desenfreada aos comportamentos competitivos que atualmente caracterizam as ações hegemônicas (SANTOS, 2000, 2019).

\section{Referências}

ALENCAR, J. L.; OLIVEIRA, M. A. da C. As cebs à luz da teologia da libertação e sua relação com os movimentos sociais. In: XIV Simpósio Nacional da ABHR, 15 a 17 de abril de 2015, Juiz de Fora, MG, p. $1135-1147$.

BECKER, Bertha K. Revisão das políticas de ocupação da Amazônia: é possível identificar modelos para projetar cenários? Parcerias estratégicas, v. 6, n. 12, p. 135-159, 2001.

BETO, Frei. O que é comunidade de base. São Paulo, Brasiliense, 1981.

CARVALHO, Guilherme. Grandes projetos de infraestrutura, conflitos e violação de direitos na Panamazônia. Revista Latinoamericana de Derecho y Políticas Ambientales, v. 2, n. 2, p.1-18, 2012.

CASTRO, Edna. Expansão da fronteira, megaprojetos de infraestrutura e integração sul-americana. Caderno CRH, v. 25, n. 64, p. 45-61, 2012.

CASTRO, Edna. Amazônia na encruzilhada entre o saque colonial e as lutas de resistência. In: Edna Castro. (Org.). Territórios em transformação na Amazônia. Belém: UFPA/NAEA, 2017, v. 1, p. 1948.

CASTRO, Edna. Neoextractivismo en la mineria, prácticas coloniales y lugares de resistencia en Amazonia, Brasil. Perfiles Económicos, v. 5, p. 35-76, 2018.

CASTRO, Edna M. R.; CAMPOS, Indio (Org.). Formação Socioeconômica da Amazônia. Belém: NAEA/UFPA, 2015. p. 15-36.

CASTRO, Edna; FIGUEIREDO, Sílvio; RIVERO, Sérgio; ALMEIDA, Oriana. Pensamento crítico sobre a Amazônia e o debate sobre desenvolvimento. Papers do NAEA (UFPA), v. 1, p. 1-19, 2018.

CASTRO, Edna; RODRIGUES, Jondison C.; HAZEU, Marcel; ALONSO, Sara. Mega projetos e novos territórios do capital: infraestrutura de transporte e portuária na Amazônia. In: CASTRO, Edna; FIGUEIREDO, Silvio (Org.). Sociedade, Campo Social e Espaço Público. Belém: NAEA, 2014. p. 1242.

COUTINHO, Sérgio R. Comunidades Eclesiais de Base: presente, passado e futuro. Interações - Cultura e Comunidade, v.4 n.6, p.173-185, 2009.

COUTINHO, Marcius V. Terras de identidade e terras de conflito: movimento social ribeirinho e regularização fundiária nas ilhas e várzeas de Abaetetuba - PA. Estudos Sociedade e Agricultura, v. n. 1, p. 33-64, 2018.

DUPRAT, Deborah. A convenção 169 da OIT e o direito à consulta prévia, livre e informada. RCJ Revista Culturas Jurídicas, v. 1, n. 1, 2014. 
EIA/RIMA - Estudo de Impacto Ambiental/ Relatório de Impacto Ambiental. Terminal de Uso Privativo - TUP Abaetetuba (Cargill). 2018. Disponível em: <https://www.semas.pa.gov.br/documentos/estudos-de-impacto-ambiental/>. Acesso: 12 jan. 2019.

FERNANDES, Bernardo M. Movimentos socioterritoriais e movimentos socioespaciais: contribuição teórica para uma leitura geográfica dos movimentos sociais. Revista NERA (UNESP), v. 8, n. 6, p. 1434, 2005.

FERNANDES, Bernardo M. Sobre a tipologia de territórios. In: SAQUET, M. A.; SPOSITO, E. S. Territórios e territorialidades: teorias, processos e conflitos. São Paulo: Expressão Popular, 2009. p. $197-216$.

FERNANDES, Bernardo M. Territorios: teoría y disputas por el desarrollo rural. Novedades en población, n.17, p. 116-133, 2013a.

FERNANDES, Bernardo M. Construindo um estilo de pensamento na questão agrária: o debate paradigmático e o conhecimento geográfico. Tese (Doutorado em Geografia), Universidade Estadual Paulista, Presidente Prudente, 2013b.

GAGLiANO, Francesco. Pedro Casaldáliga, 90 anos: bispo, poeta e defensor intransigente da dignidade humana. Disponível em: <http://www.ihu.unisinos.br/78-noticias/575711-pedro-casaldaliga-90-anosbispo-poeta-e-defensor-intransigente-da-dignidade-humana>. Acesso em: 18 mar. 2019.

GUDYNAS, Eduardo. Estado compensador y nuevos extractivismos - las ambivalencias del progresismo sudamericano. Nueva Sociedad, n. 237, p.128-146, 2012.

HAESBAERT, Rogério. Da desterritorialização à multiterritorialidade. In: X Encontro de Geógrafos da América Latina, 20 a 26 de março de 2005, Universidade de São Paulo. p. 6774-6792.

HARVEY, David. A urbanização e as crises. A urbanização e as crises. Pós, v. 19, n. 32, p. 10-24, 2012.

HEWITT, W. E. Strategies for Social Change Employed by Comunidades Eclesiais de Base (CEBs) in the Archdiocese of São Paulo. Journal for the Scientific Study of Religion, v. 25, n, 1, p. 16-30, 1986.

HEWITT, W. E. Religion and the consolidation of democracy in Brazil: the role of the Comunidades Eclesiais de Base (CEBs). Sociology of Religion, v. 51, n 2, p. 139-152, 1990.

LOUREIRO, Violeta R. Amazônia: uma história de perdas e danos, um futuro a (re)construir. Estudos Avançados, v.16, n. 45, p. 107-121, 2002.

LOUREIRO, Violeta R. A Amazônia no século 21: novas formas de desenvolvimento. REVISTA DIREITO GV, v. 8, n. 2, p. 527-552, 2012.

MITIDIERO JUNIOR, Marco A. A Geografia dos documentos eclesiais: o envolvimento da igreja católica com a questão agrária brasileira. Revista Crítica Histórica, v. 1, n. 1, p. 242-258, 2010.

NOVA CARTOGRAFIA SOCIAL DA AMAZÔNIA. Oficina de mapeamento social na ilha do capim, município de Abaetetuba, PA. 2016. Disponível em: http://www.novacartografiasocial.com.br/oficinade-mapeamento-social-na-ilha-do-capim-município-de-abaetetuba-pa/. Acesso em: 23 fev. 2019.

POJO, Eliana C.; ELIAS, Lina G. D. O cotidiano das águas na tradição quilombola da comunidade do Rio Baixo Itacuruçá- Abaetetuba, PA. Revista Sociais \& Humanas, v. 31, n. 3, 2018.

RINCÓN, Luis Felipe; FERNANDES, Bernardo M. Territorial dispossession: dynamics of capitalist expansion in rural territories in South America, Third World Quarterly, v.39m n. 11, p. 2085-2102, 2018.

RODRIGUES, Jondison C. Educação Ambiental e estratégias empresariais na área portuária: um estudo da Companhia Docas do Pará (CDP). 2012. Dissertação (Mestrado em Ciências Ambientais) Belém, PA: UFPA. 2012. 
RODRIGUES, Jondison C. O Estado a contrapelo: lógica, estratégias e efeitos de complexos portuários no oeste do Pará. 383 f. Tese (Doutorado em Desenvolvimento Socioambiental) - Universidade Federal do Pará, Núcleo de Altos Estudos Amazônicos, Belém, 2018a.

RODRIGUES, Jondison C. O Arco Norte e as políticas públicas portuárias para o Oeste do estado do Pará (Itaituba e Rurópolis): apresentação, debate e articulações. Revista NERA (UNESP), v. 21, n. 42, p. 202228, 2018b.

RODRIGUES, Jondison C.; RODRIGUES, Jovenildo C.; CASTRO, Edna. Transporte hidroviário, portos e terminais interiores na Amazônia brasileira: uma análise sobre seus papéis na política pública territorial. Geo UERJ, v. 1, n. 25, p. 115-137, 2014.

RODRIGUES, Jondison C.; RODRIGUES, Jovenildo C. A produção de complexos portuários no município de Itaituba, Oeste do Pará: lógicas e contradições das políticas públicas. Caminhos de Geografia (UFU), v. 16, n. 56, p. 1-21, 2015.

RODRIGUES, Jondison C.; RODRIGUES, Jovenildo C.; LIMA, Ricardo A. "Portos do agronegócio" e produção territorial da cidade de Itaituba, na Amazônia Paraense. Geosul, v. 34, n. 71, p. 356-381, 2019.

SANTOS, Milton. Por uma outra globalização: do pensamento único à consciência universal. São Paulo: Record, 2000.

SANTOS, Milton. Encontro com Milton Santos ou O Mundo Global visto do lado de cá. Disponível em: <https://www.youtube.com/watch?v=-UUB5DW_mnM>. Acesso em 19 jan. 2019.

SOBREIRO-FILHO, José. O movimento em pedaços e os pedaços em movimento: da ocupação do Pontal do Paranapanema à dissensão nos movimentos socioterritoriais camponeses. $546 \mathrm{f}$. Dissertação (Mestrado em Geografia) - Universidade Estadual Paulista, Presidente Prudente, 2013.

SOBREIRO-FILHO, José. Movimentos socioespaciais, socioterritoriais, manifestações e as redes sociais: das manifestações internacionais ao Movimento Passe Livre-SP. GeoGraphos, v. 6, n. 73, p. 1-29, 2015a.

SOBREIRO-FILHO, José. O(s) movimento(s) por trás das dissensões: rupturas, agregação, lideranças e poder nas dissidências do Pontal do Paranapanema. Revista NERA (UNESP), v. 27, n. 27, p. 64-95, $2015 b$.

SOBREIRO-FILHO, José. Contribuição à construção de uma teoria geográfica sobre movimentos socioespaciais e contentious politics: produção do espaço, redes e lógica-racionalidade espaço-temporal no Brasil e Argentina. 423 f. Tese (Doutorado em Geografia), Universidade Estadual Paulista, Presidente Prudente, 2016.

SOUZA, Antônio A. CEBs: uma igreja que nasce do povo. Cadernos Cajuína, v. 3, n. 3, p. 3-16, 2018. 